\title{
Primary health care assessment from the users' perspectives: a systematic review
}

\author{
Avaliação da atenção básica à saúde sob a ótica dos usuários: uma revisão sistemática \\ Evaluación de la atención básica de salud bajo la óptica de los usuarios: una revisión sistemática
}

Weslla Karla Albuquerque Silva de Paula ${ }^{1}$, Isabella Chagas Samico ${ }^{2}$, Maria de Fátima Costa Caminha², Malaquias Batista Filho $^{2}$, Suzana Lins da Silva ${ }^{1}$

How to cite this article:

Paula WKAS, Samico IC, Caminha MFC, Batista Filho M, Silva SL. Primary health care assessment from the users' perspectives: a systematic review. Rev Esc Enferm USP. 2016;50(2):331-340. DOI: http://dx.doi.org/10.1590/S0080-623420160000200021

${ }^{1}$ Instituto de Medicina Integral Prof. Fernando Figueira, Recife, PE, Brazil.

${ }^{2}$ Instituto de Medicina Integral Prof. Fernando Figueira, Programa de Pós-Graduação em Saúde Materno Infantil, Recife, PE, Brazil.

\section{ABSTRACT}

Objective: Analyze the evaluation of the attributes of primary care made by users of basic units of Brazilian health by using PCATool instrument adapted to Brazil. Method: A systematic literature review conducted in the PubMed database, IBECS, LILACS, SciELO and BDTD. Results: 4,405 documents were found, selected 23 full texts. After Full reading and application of eligibility criteria, 14 articles were evaluated. The studies showed that primary care performs well in longitudinality attributes, completeness and coordination and worse performance on attributes access first contact, family counseling and community orientation, even in the basic units with the Family Health. Conclusion: The users of basic health units assessed as unsatisfactory attributes considered essential for a health care more equitable and competing for user autonomy and social control. It is inferred that there are still obstacles hindering user access to basic health services and care actions are still being developed without favoring user participation and the community context in which they live.

\section{DESCRIPTORS}

Primary Health Care; Health Services Evaluation; Program Evaluation; Review. 


\section{INTRODUCTION}

The Alma-Ata Declaration advocated that, in order to reach the goal for delivering "Health for all by the year 2000 "(1), economic and social development of the countries was necessary, as well as government policies and actions involving other sectors, and not only the health system, and that it could rely on popular participation. Thus, Primary Health Care (PHC) was essential for achieving this objective. Assuming it as a broad, equable health care system, and closer to the health needs of individuals and communities, people's first contact with the health system should occur through the PHC network ${ }^{(1)}$.

Despite the broader concept adopted by Alma-Ata, different PHC approaches were endorsed. In developed countries, especially in Europe, it refers to the entrance door of the health care system and the place of continuous health care for the majority of the population, centered in the general practitioner or specialized in family medicine. On the other hand, in developing countries, $\mathrm{PHC}$ originally has a selective nature, based on the recommendations of international organizations, such as the World Bank, following a neoliberal policy, reductionist in terms of health spending, and restriction towards the State role, thus privileging lowincome populations and specific programs, such as the socalled basic service staples, especially in the area of maternal and child health care. Although successful in some of its interventions, a great deal of criticism was raised regarding the selective approach of PHC, particularly for not taking into consideration all health determinants, thus ignoring social and economic contexts in the process ${ }^{(2)}$.

Regarding the divergence for defining the terms Primary Health Care, Primary Care (PC) and Basic Care (BC), in Brazil, at the end of the 1990's, official documents from the Ministry of Health (MH) had already included the term basic care in the context of organizing services, probably due to its own history implementing the Unified Health System (SUS, as per its acronym in Portuguese), as it elaborated proposals for decentralizing and organizing the system or as a way of differentiating primary care from the propositions that cut down PHC to mere service packages ${ }^{(3)}$.

It was only in 2006, with the National Primary Care Policy (PNAB, as per its acronym in Portuguese) approval, through Ordinance No. 648 ${ }^{(4)}$, that the guidelines and regulations for organizing $\mathrm{BC}$ were established, and updated later through Ordinance No. $2488 / 2011^{(5)}$. In it, there is a journal oriented towards Alma-Ata ideology and the broader concept on health anchored to the Federal Constitution of 1988, which guided the creation of the SUS. According to the PNAB, PHC and $\mathrm{BC}$ are taken as synonyms, regarded as a "set of actions for health, at the individual and collective level, that consists of health care promotion and protection, prevention of complications, diagnosis, treatment, rehabilitation, damage reduction and health maintenance with the aim of developing an integrated care that generates an impact on health and the autonomy of people and determinants, and health constraints in the communities"(5).
The rearrangement of the health system coordinated by PHC goes beyond the concept of selective care and the simple level of care, but rather as an integrated part of the health care network ${ }^{(6)}$. As a health care system organizer, according to Starfield's ${ }^{(7)}$ theoretical framework, PHC should carry on the first contact, longitudinality, comprehensiveness, coordination, family orientation, community orientation, and cultural competence features. Such a concept is evidenced in the PNAB text, suggesting convergence between official documents from the $\mathrm{MH}$ and the conceptual framework from the author, which also served as the basis for the current study ${ }^{(8)}$.

In order to assess the presence and extension of the referred attributes, the author and colleagues developed, at John Hopkins Primary Care Policy Center (PCPC), a self-applicable tool called Primary Care Assessment Tool (PCATool), which allows to measure PHC attributes from the perspective of user's (children and adult versions) and health professionals ${ }^{(7,9)}$. It is based on the health service quality assessment model introduced by Donabedian, which uses the triad structure, process, and result ${ }^{(7,10)}$.

Even with the availability of other tools for assessing PHC, the PCATool was regarded as the most comprehensive and adequate for measuring the attributes necessary for PHC, for allowing the evaluation of the characteristics of the structure and the process of primary care services, and especially for being available in different formats ${ }^{(11,12)}$. Adaptations on the original PCATool were necessary for the validation process for use in Brazil, taking into consideration the cultural characteristics of the population and the national health system ${ }^{(13)}$. Primary care services in Brazil have as a feature the Family Health Strategy (FHS), which since 1994 has served as a reorientation model for primary care, based on the interdisciplinary teamwork responsible for geographically defined territory ${ }^{(5)}$. The PCATool was referred as the tool that allows a closer assessment of Family Health ${ }^{(12)}$, including a $\mathrm{MH}$ publication orienting its use for assessing Brazilian health equipment based on $\mathrm{PHC}^{(10)}$.

This specific tool has versions adapted and validated for the Brazilian reality ${ }^{(13-15)}$ and several studies are already applying it for assessing the presence and extent of PHC attributes ${ }^{(14,16-19)}$. However, searching the bibliographical database from MEDLINE data, via PubMed and SciELO, no systematic literature review was found for comprehensively accessing the assessment of these services, particularly from the perspective of users, who serve as guiding parameters for the quality of the care provided.

In this context and, taking into consideration the assumption that units with Family Health Care are more PHC-oriented than traditional Basic Health Units (BHU) ${ }^{(16,19)}$, this study focused on analyzing the assessment of PHC attributes carried out by users of Brazilian primary health units, by using the adaptations of the PCATool for use in Brazil.

\section{METHOD}

A systematic literature review published between 2000 and 2013 was carried out, taking into account that it was in 
the beginning of the last decade that the first publications on the PCATool were released. Data collecting took place in January 2014 after the following research question: What is the assessment of primary care made by users of Brazilian primary health units (family and traditional health units), by using the adaptations of the Primary Care Assessment Tool (PCATool) for Brazil? The formulation of the question considered the acronym PICOS (Participants, Interventions, Comparisons, Outcomes, Studies) ${ }^{(20)}$, a strategy also followed for defining the eligibility criteria. Studies (original articles, dissertations, and theses) that applied the PCATool for assessing PHC attributes in Brazil, had the service users as the population, and adopted an observational design, regardless of the type of research, were included. There were no restrictions regarding the language. Studies that applied the PCATool exclusively for health professionals were excluded, as well as those that used the form readapted for the case of tuberculosis care.

In order to minimize possible publication biases, a broad database research was conducted using the following information sources: MEDLINE/PubMed (Medical Literature Analysis and Retrieval System Online), LILACS (Literatura Latino Americana e do Caribe em Ciências da Saúde), IBECS (Índice Bibliográfico Espanhol de Ciências da Saúde), and SciELO (Scientific Electronic Library Online). Additionally, data from dissertations and theses published by the Biblioteca Digital Brasileira de Teses e Dissertações (BDTD) and articles identified in the references of publications on the subject were investigated.

Search strategy was carried out by two independent researchers. The results found were compared and discrepancies were solved by consensus. The steps taken for data search, study selection, and extraction are described below:

Step 1: For searching in MEDLINE/PubMed the corresponding health descriptors in English were chosen (Medical Subject Headings - Mesh), combined with Boolean data types AND and OR, ((("Primary Health Care"[Mesh]) AND ("Program Evaluation"[Mesh]) OR "Health Services Research"[Mesh]) AND “Brazil”[Mesh]), arranged in a format to cover all the possibilities and provide more sensitiveness and specificity to the search. As for SciELO, LILACS, and IBECS, adaptations were made using the words "Primary health care", "Health services assessments", and "Assessment of health programs and projects", equally matched with the Boolean data types AND and OR.

Step 2: By reading the titles and, when necessary, the respective summaries, all texts found were evaluated according to the adequacy of the proposed topic. Those addressing other issues were excluded in this step, as well as those that were duplicated.

Step 3: Data drawn from articles were transcribed to electronic format including the information on title, authors, year of publication, journal, design, study setting, outcome, sample, results and risk of bias. As for the users, the variables that would allow the characterization of this population (gender, age, level of education) were examined. On the other hand, as for the PHC attributes, the variables analyzed were those related to the primary outcome of interest, in other words, essential attributes: access to first contact, longitudinality, comprehensiveness, coordination of the care and those related to secondary outcomes, in other words, derived attributes: family orientation, community orientation, and cultural competence ${ }^{(7)}$.

Aiming at assessing the methodological quality of the studies, the Quality Assessment Tool for Quantitative Studies $^{(21)}$ developed and tested ${ }^{(22)}$ by the Effective Public Health Practice Project (EPHPP), linked to the McMaster University, Canada, was applied. This tool was chosen because it was elaborated with the purpose of providing quality to systematic reviews, which promotes evidence to support interventions on the public health area. Additionally, the Cochrane Public Health Review Group recommended evaluating the quality of the studies and the risk of bias ${ }^{(23)}$. The original tool consists of 22 items divided into eight sets (A-H): selection biases, study design, confounding factors, blinding, data collection method, dropouts and give-ups, intervention integrity, and analysis. Assessing the first six sets (A-F), they can be separately classified as high, moderate, or low according to the definition for each of these criteria. At the end, a global index is obtained classifying each article into: high (lack of weak items), moderate (presence of one weak item only), or low (presence of two or more weak items) ${ }^{(21)}$.

Furthermore, the publications were qualified according to the levels of evidence for efficacy/effectiveness studies, based on The Joanna Briggs Institute ${ }^{(24)}$ approach system: Level 1 - Experimental designs: 1.a - Systematic review of randomized controlled trials; $1 . b$ - Systematic review of randomized controlled trials and other study designs; 1.c - Randomized controlled trial; 1.d - Pseudo-randomized controlled trials. Level 2 - Quasi-experimental designs: 2.a - Systematic review of quasi-experimental studies; $2 . \mathrm{b}$ - Systematic review of quasi-experimental and other lower study designs; 2.c - Quasi-experimental prospectively controlled study; 2.d - Pre-test and post-test or historic/retrospective control group study. Level 3 - Observational - analytic designs: 3.a - Systematic review of comparable cohort studies; 3.b - Systematic review of comparable cohort and other lower study designs; 3.c - Cohort study with control group; 3.d - Case control study; 3.e - Observational studies without a control group; Level 4 - Observational - descriptive studies; 4.a - Systematic review of descriptive studies; 4.b - Cross-sectional study; 4.c - Case series; 4.d - Case study. Level 5 - Expert opinion - Bench laboratory research: 5.a - Systematic review of expert opinion; 5.b - Expert consensus; $5 . c-$ Bench lab research/single expert opinion.

Descriptive analysis of data matched with theoretical knowledge on the topic was conducted in order to collaborate with health managers and professionals for decisionmaking based on evidences. Bibliographical references identified through search strategy were managed using EndNote X7 software (Thomson Reuters).

\section{RESULTS}

\section{Selection OF Studies}

Initially, 4,250 articles were found, plus 4 through manual search, and 155 dissertations/theses, totaling 4,405 
documents. After eliminating duplicates, from studies whose titles/abstracts did not correspond to the eligibility criteria and full texts were not available, 23 titles were assessed. After a new reading, nine articles were excluded: six for having applied the PCATool exclusively to health professionals, two for having used its readapted form for tuberculosis care, and one for presenting only the details of the methods used for the validation of the PCATool Brazil - adult version that, therefore, did not yield results ${ }^{(13)}$, thus not meeting the inclusion criteria. At the conclusion of the selection process, the systematic review covered 14 studies. The flowchart of the selection of the documents for each step is summarized in Figure 1 and followed the PRISMA (Preferred Reporting Items for Systematic Reviews and Meta-Analyses) ${ }^{(25)}$.

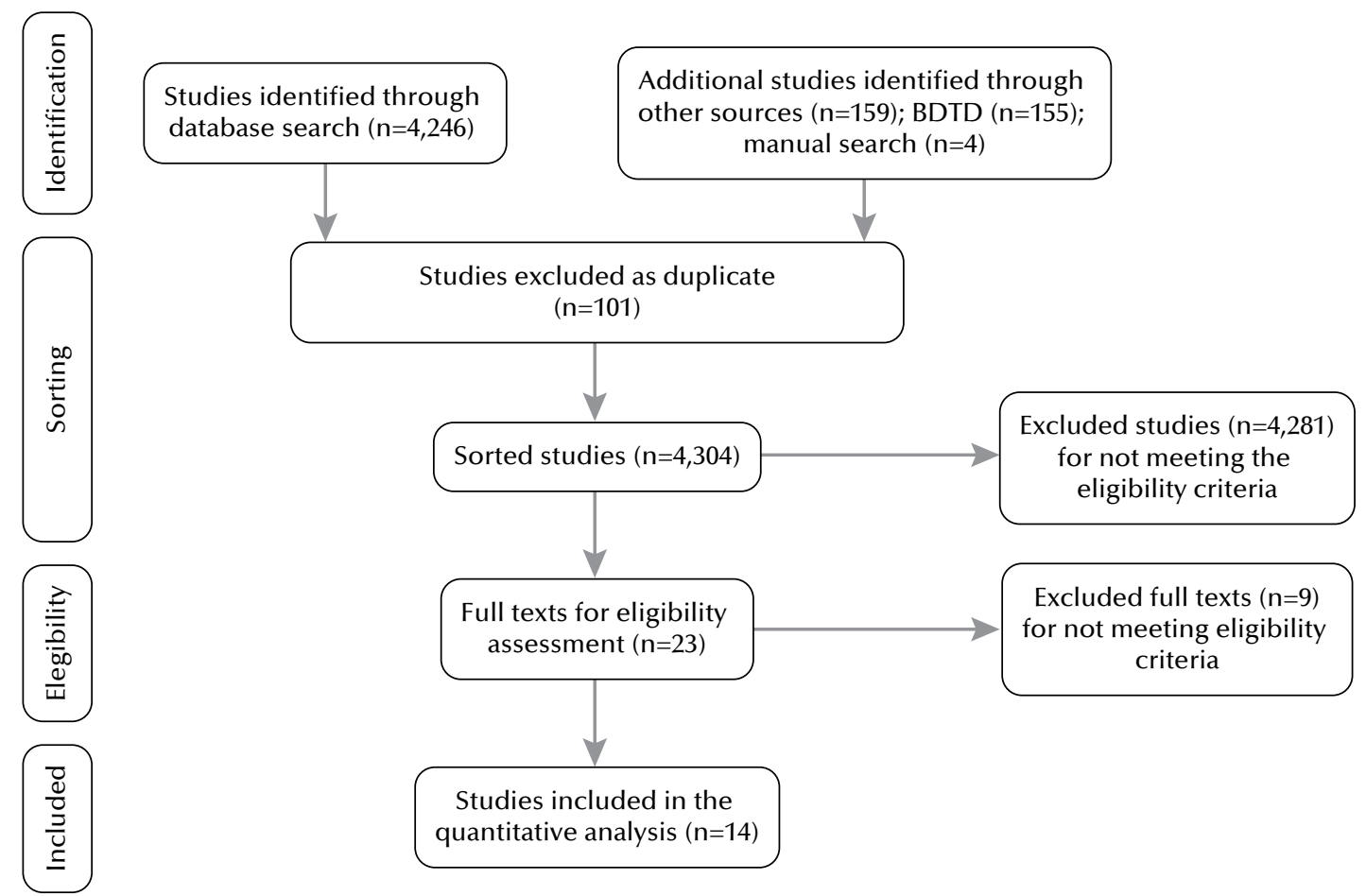

Figure 1 - Flowchart of the selection process of studies for systematic review - Recife, PE, Brazil, 2014.

\section{ChARACTERISTICS OF THE STUDIES AND PARTICIPANTS}

Approximately $87 \%$ of the selected studies were conducted in cities located in the South and Southeast regions of $\mathrm{Brazil}^{(14-15,18-19,26-33)}$ and $67 \%$ made the comparison related to presence and extent of PHC attributes in the family health care units and traditional primary units ${ }^{(14,17-19,26-29,32)}$. In all, 12,643 users participated in the studies, with samples varying between $44^{(33)}$ and $2,923^{(26)}$ subjects. Only three studies did not present any sociodemographic characteristic of the participants ${ }^{(17,33-34)}$. Women prevailed and the mean age of the participants ranged between $26.5^{(19)}$ and $46.7^{(18)}$ years. There were heterogeneity in data regarding education, whereas some studies took this variable as categorical, with different intervals of class ${ }^{(14,18-19,26-27,32)}$, others considered it as a continuous variable (mean: $7.4^{(15)}$ and 8.8 years $\left.{ }^{(18)}\right)$. On the other hand, four studies did not provide information on the level of education of the participants ${ }^{(17,28,33-34)}$. Chart 1 summarizes the characteristics of each study and the main outcomes.

Chart 1 - General characteristics of the studies published between 2000 and 2014 on the assessment of PHC attributes, using the Primary Care Assessment Tool (PCATool) - Recife, PE, Brazil, 2014.

\begin{tabular}{|l|l|l|l|}
\hline Author (year) & \multicolumn{1}{|c|}{ Study location } & \multicolumn{1}{|c|}{$\begin{array}{c}\text { Study design/Level of } \\
\text { evidence/Sample }\end{array}$} & \multicolumn{1}{c|}{ Main results } \\
\hline $\begin{array}{l}\text { Almeida C, } \\
\text { Macinko J } \\
(2006)^{(14)}\end{array}$ & Petrópolis, RJ & $\begin{array}{l}\text { Cross-sectional/4.b/469 } \\
\text { users; 33 health } \\
\text { professionals and 6 } \\
\text { supervisors/managers }\end{array}$ & $\begin{array}{l}\text { In general, FHUs showed better performance, when compared to } \\
\text { the traditional BHUs. Low scores in the attributes were observed: } \\
\text { access, family and community orientation for both models. }\end{array}$ \\
\hline $\begin{array}{l}\text { lbañez } \\
\text { N et al. } \\
(2006)^{(26)}\end{array}$ & $\begin{array}{l}\text { 62 cities with more than } \\
100,000 \text { inhabitants in the } \\
\text { state of São Paulo (except } \\
\text { for the capital) }\end{array}$ & $\begin{array}{l}\text { Cross-sectional/4.b/ } \\
\text { Users/caregivers } \\
(2,923), \text { and health care } \\
\text { professionals (167) }\end{array}$ & $\begin{array}{l}\text { PHC was qualified as unsatisfactory. In almost all aspects, the } \\
\text { clusters with more favorable social indicators showed higher } \\
\text { level of satisfaction. Professionals from FHS units assessed their } \\
\text { performance as the best. }\end{array}$ \\
\hline $\begin{array}{l}\text { Harzheim } \\
\text { E et al. } \\
(2006)^{(15)}\end{array}$ & Porto Alegre, RS & $\begin{array}{l}\text { Cross-sectional/4.b/468 } \\
\text { caregivers of children } \\
\text { from 0-2 years }\end{array}$ & $\begin{array}{l}\text { The PCATool-Brazil has adequate validity and reliability, and } \\
\text { could constitute a national tool for assessing primary health care } \\
\text { after its application in other demographic contexts. }\end{array}$ \\
\hline
\end{tabular}




\begin{tabular}{|c|c|c|c|}
\hline $\begin{array}{l}\text { Elias PE et al. } \\
(2006)^{(28) \ddagger}\end{array}$ & São Paulo, SP & $\begin{array}{l}\text { Cross-sectional/ } / 4 \cdot b / 1.117 \\
\text { users } \\
\text { It does not mention total } \\
\text { of professionals and } \\
\text { participant managers }\end{array}$ & $\begin{array}{l}\text { The perceptions of the managers/professionals are very similar } \\
\text { in all studied aspects and, compared with the users, are always } \\
\text { better. Accessibility, community and family orientation attributes } \\
\text { were low in both, the FHS units, as well as the traditional BHU } \\
\text { for both models, where the IAB measured by the users was } \\
\text { higher for the FHS. }\end{array}$ \\
\hline $\begin{array}{l}\text { Macinko } \\
\text { J, Almeida } \\
\text { C, Sá PK } \\
(2007)^{(29)}\end{array}$ & Petrópolis, RJ & $\begin{array}{l}\text { Cross-sectional/4.b/468 } \\
\text { users }\end{array}$ & $\begin{array}{l}\text { In general, entrance door, comprehensiveness, family and } \\
\text { community orientation were significantly higher for the FHU } \\
\text { users }(p<0.05) \text { than the users of traditional services. }\end{array}$ \\
\hline $\begin{array}{l}\text { Oliveira } \\
\text { MMC } \\
(2007)^{(18)}\end{array}$ & Porto Alegre, RS & $\begin{array}{l}\text { Cross-sectional/4.b/1,393 } \\
\text { adult users }\end{array}$ & $\begin{array}{l}\text { Significant differences among PHC scores for different services } \\
\text { were observed. Except for the access/use attribute, all the } \\
\text { remaining were lower in most of the services. }\end{array}$ \\
\hline $\begin{array}{l}\text { van Stralen } \\
\text { CJ et al. } \\
(2008)^{(17)}\end{array}$ & $\begin{array}{l}\text { GO: Águas Lindas de } \\
\text { Goiás, Anápolis, Aparecida } \\
\text { de Goiânia, Goiânia, } \\
\text { Luziânia, Rio Verde, and } \\
\text { Valparaiso de Goiás; } \\
\text { MS: Campo Grande, and } \\
\text { Dourados }\end{array}$ & $\begin{array}{l}\text { Cross-sectional/4.b/Users } \\
\text { (490) and caregivers ( } 133) \\
\text { health care professionals } \\
\text { with higher education } \\
\text { (302) and elementary/high } \\
\text { school (207). }\end{array}$ & $\begin{array}{l}\text { The perception of the professionals was more favorable than that } \\
\text { of the users. As for the extensions, except for access extension, } \\
\text { family health strategy (FHS) units were more favorable. Lower } \\
\text { scores were observed in the attributes: access, family and } \\
\text { community orientation in both models. }\end{array}$ \\
\hline $\begin{array}{l}\text { Zils et al. } \\
(2009)^{(30) \ddagger}\end{array}$ & Porto Alegre, RS & $\begin{array}{l}\text { Cross-sectional/4.b/1,154 } \\
\text { users }\end{array}$ & $\begin{array}{l}\text { Significant differences was observed in } 12 \text { variables reflecting } \\
\text { satisfaction, always demonstrating higher satisfaction of users, } \\
\text { who classified the PHC service with high scores. }\end{array}$ \\
\hline $\begin{array}{l}\text { Leão CDA, } \\
\text { Caldeira } \\
\text { AP, Oliveira } \\
\text { MMC. } \\
(2011)^{(19)}\end{array}$ & Montes Claros, MG & $\begin{array}{l}\text { Cross-sectional } / 4 \cdot \mathrm{b} / 350 \\
\text { caregivers of children from } \\
0-2 \text { years }\end{array}$ & $\begin{array}{l}\text { Low scores were found in the attributes of } 1^{\text {st }} \text { contact access, } \\
\text { comprehensiveness (available services), family and community } \\
\text { orientation. The overall score showed a value closer to the ideal } \\
\text { among children who used FHS units and higher score attributed } \\
\text { by the caregivers who used other services. }\end{array}$ \\
\hline $\begin{array}{l}\text { Pereira } \\
\text { MJB et al. } \\
(2011)^{(31) \ddagger}\end{array}$ & $\begin{array}{l}\text { A town in the interior of } \\
\text { the state of São Paulo }\end{array}$ & $\begin{array}{l}\text { Cross-sectional } / 4 . b / 55 \\
\text { adult users }(>18 \text { years }) \\
\text { of a BHU from the } \\
\text { referred town }\end{array}$ & $\begin{array}{l}\text { The attributes of entrance door, service staff, coordination, and } \\
\text { relationship were better assessed, showing values above the } \\
\text { average (7.0). Professional training, access, community and } \\
\text { family orientation showed the worst performance. }\end{array}$ \\
\hline $\begin{array}{l}\text { Pinto MEB } \\
(2012)^{(27)}\end{array}$ & Porto Alegre, RS & $\begin{array}{l}\text { Cross-sectional/4.b/1,200 } \\
\text { adult users }\end{array}$ & $\begin{array}{l}\text { The four preventive practices were carried out with high level of } \\
\text { PHC orientation, and even in these services timely orientation } \\
\text { about promotion and prevention was below the ideal. The results } \\
\text { showed a direct link among these practices and better quality of } \\
\text { PHC attributes. }\end{array}$ \\
\hline $\begin{array}{l}\text { Oliveira } \\
\text { VBCA } \\
(2012)^{(32)}\end{array}$ & Colombo, PR & $\begin{array}{l}\text { Cross-sectional } / 4 . \mathrm{b} / 482 \\
\text { subjects, namely } 235 \text { from } \\
\text { FHS and } 247 \text { from BHU. }\end{array}$ & $\begin{array}{l}\text { FHS units received higher scores than the minimum required in } \\
\text { affiliation, coordination, comprehensiveness, family orientation, } \\
\text { and accessibility. As for the BHU, all scores were below the ideal } \\
\text { for PHC. }\end{array}$ \\
\hline $\begin{array}{l}\text { Braz JC } \\
(2012)^{(34)}\end{array}$ & Vitória da Conquista - BA & $\begin{array}{l}\text { Cross-sectional } / 4 . b / 271 \\
\text { caregivers of children } \\
<1 \text { year from the areas } \\
\text { covered by the } 13 \text { family } \\
\text { health care teams in } \\
\text { the urban area of the } \\
\text { referred city. }\end{array}$ & $\begin{array}{l}\text { The results revealed higher scores in only four aspects: level } \\
\text { of affiliation, access to first contact (usage), longitudinality, } \\
\text { and coordination (information system). Assessing the aspects } \\
\text { as a whole, the result was essential and overall scores had } \\
\text { low values. }\end{array}$ \\
\hline $\begin{array}{l}\text { Furtado MCC, } \\
\text { Braz JC, Pina } \\
\text { JC, Mello DF, } \\
\text { Lima RAG } \\
(2013)^{(33) \ddagger}\end{array}$ & $\begin{array}{l}\text { A town located in the } \\
\text { northeast of the state of } \\
\text { São Paulo }\end{array}$ & $\begin{array}{l}\text { Cross-sectional } / 4 . \mathrm{b} / 44 \\
\text { mothers of children }<1 \\
\text { year from the area covered } \\
\text { by the FHS }\end{array}$ & $\begin{array}{l}\text { High level of affiliation among mothers and the health care } \\
\text { unit to which they are member. Accessibility (use of services), } \\
\text { longitudinality, health care coordination, comprehensiveness } \\
\text { (services provided), and family and community orientation } \\
\text { were considered high for more than } 80 \% \text { of the interviewed. } \\
\text { Comprehensiveness - services available - held the lowest score. }\end{array}$ \\
\hline
\end{tabular}

\section{Methodological QUality ASSESSMENT Of THE StUdies}

Some of the criteria comprising the Quality Assessment Tool for Quantitative Studies ${ }^{(21)}$ were not totally met. In three studies, individuals selected for participating in the studies probably did not represent the target population, and were classified as low in this criterion ${ }^{(18,33-34)}$.

As for the study design, since the studies were all considered sectional observational studies ${ }^{(14-15,17-19,26,28-34)}$ and, by their nature, did not have control and intervention groups, in order for not classifying them as low this item was not assessed and the next criterion was then followed.
Assessing confounding factors, out of eight articles that evaluated diverse PHC services, half did not show considerable differences in the characteristics of the users between groups (FHS and traditional $\mathrm{BHC}$ units) $)^{(14,26,29,32)}$, and in cases with notable differences the control of possible confounding factors were carried out ${ }^{(18-19,27)}$. However, in one article it was not possible to evaluate the differences between the groups, since the information on users' characteristics was not presented ${ }^{(17)}$, qualifying this criterion as low.

As for the blinding criterion, based on the design of the studies included in this review (observational, crosssectional studies), the blinding of the evaluators in relation 
to the outcome and the participants in the research is not applicable. Thus, the study did not evaluate this item.

The totality of the articles was classified as high according to the data collecting tool, since they demonstrated validity and reliability. Six studies ${ }^{(14,17,26,28-29,31)}$ used the PCATool version validated and adapted for Brazil, based on a crosssectional study conducted in the city of Petrópolis- $\mathrm{RJ}^{(14)}$, and seven $^{(15,19,27,30,32-34)}$ applied the PCATool-Brazil(10), another version of the tool adapted and validated by the research team from the Universidade Federal do Rio Grande do Sul. One study ${ }^{(18)}$ only used the original PCATool, adult version ${ }^{(9)}$.

Finally, as for quitting and dropouts, the articles did not take this criterion into account, considering that in this kind of study design (sectional/cross-sectional) long-term follow-up of the participants does not take place.

\section{Primary Health Care attributes}

It is important to emphasize that, since the tools are adapted from the original PCATool, the scales used for defining high or low scores differed according to the answer options of each questionnaire. The studies that applied the PCATool version validated in the city of Petrópolis$\mathrm{RJ}^{(14,17,26,28-29,31)}$ worked with scales that varied between 0 and 5 , being classified as low value scores $<3.3$. On the other hand, studies that applied the PCATool-Brazil ${ }^{(10)}$ used scales from 0 to 10 , qualifying low scores as $<6.6^{(15,19,27,30,32-}$ 34). The same scale was adopted by the Brazilian Ministry of Health ${ }^{(10)}$.

Considering access to first contact attribute, at large, low scores $^{(14-15,17,19,26,28-29,34)}$ were observed, even when considering the FHS units. The attribute longitudinality was well-assessed by the users in most of the studies ${ }^{(14-15,17,19,26,28,31,33-34)}$. As for comprehensiveness, a good performance of this attribute was seen at the sampled PHC units ${ }^{(31,33)}$ and some studies showed a higher level in the FHS units compared with the traditional BHC units, with statistically significant differences $(\mathrm{p}<0.05)$ $(14,29,32)$. However, low scores were also found ${ }^{(17,34)}$.

In this review, a good performance of the attribute coordination was observed, with higher scores found in the Family Health Units (FHU), except for an article ${ }^{(18)}$ where a community health care service, created in the beginning of the 1980's in the city of Porto Alegre-RS, was better evaluated. Regarding the attributes derived from the family and community orientation, the assessment of the performance was far from being considered adequate in almost all studies. Nonetheless, in this aspect, higher scores were noticed in the FHU than in traditional $\mathrm{BHC}$ units.

Only five ${ }^{(14,17,26,29,31)}$ articles that used as reference the PCATool version validated and adapted for Brazil in the city of Petrópolis-RJ ${ }^{(14)}$ showed the professional training dimension. This attribute was generally well-assessed, without presenting significant differences among health care services. Only one article ${ }^{(18)}$ showed the cultural competence dimension, considering it was the only study to use the original PCATool ${ }^{(9)}$ as reference. The score of the referred attribute was considered low, showing a high score in only one community health care service and in other private service in the city of Porto Alegre-RS.
A study conducted in the state of São Paulo with the aim at stratifying PHC attributes using social indicators from the cities (clusters) found, generically, higher means adjusted from the scores in the clusters better qualified, inferring that cities with more favorable social indicators could provide better health care services. An exception was found in the dimension of the community orientation and service staff. The authors emphasize that the cities involved had low family health care coverage and suggested that clusters with better indicators should offer other types of health care services less interested in these dimensions ${ }^{(26)}$.

In a study carried out in the city of São Paulo with 1,117 users who compared the BHC and FHS by the social exclusion stratum, $\mathrm{BC}$ rates were more favorable towards $\mathrm{FHU}$ in all social exclusion stratum, whereas the rates reached were inversely proportional to the situations of exclusion, in other words, the higher the exclusion, the lower the FHS approval rate ${ }^{(28)}$.

\section{DISCUSSION}

The studies pointed out that Primary Care has good performance as for longitudinality, comprehensiveness, and coordination dimensions and poor performance in the access to first contact, family and community orientation attributes.

The accessibility and entrance door dimensions constitute some of the attributes necessary for PHC. Accessibility is measured by the presence or lack of geographic, financial, and organizational barriers that hamper meeting the needs of people's health. On the other hand, the entrance door is the first contact an individual has with the health care system, during each new problem or new health episode, excluding emergency situations ${ }^{(7)}$. The $\mathrm{PNAB}^{(5)}$ itself uses the following quote saying that primary care should be "the users' preferential contact, the main entrance door, and the PC network communication center."

It is noteworthy that the tool used in the studies included in this review were adapted for the Brazilian reality and, as such, once adjusted they became new assessment tools, justifying the use of different denominations among them. The PCATool version validated for Petrópolis-RJ ${ }^{(14)}$, for instance, shows the term access involving the location of the health care unit near the population and organizational aspects, such as days and hours the unit is opened. However, the PCATool-Brazil ${ }^{(10)}$ introduces the access to first contact attribute and divides it into two components, usage and accessibility, based on the terms used in the original tool ${ }^{(9)}$.

It is also important to highlight that the terms access and accessibility have different meanings. Access refers to something that surpasses the mere concept of an entrance door and has different dimensions: economical, technicalassistance, political, and symbolical. From the economic point-of-view, it covers the relations between supply and demand of health care services, presupposing that access to health care indirectly provides the ability to find out work and wage, thus helping to turn individuals into consumers in the market. From the technical-assistance perspective, access serves as a regulatory side of the PHC network, defining flow and capacity, and collaborating in planning the 
expansion and organization of the network. In the political aspect, access consolidation emerges through citizen participation and social control. Finally, the symbolic dimension of access has to do with the social representation of the concept of health/illness process since, depending on these concepts, means that guarantee users' entrance into the health care system could be planned ${ }^{(35)}$.

The study that evaluated the equity for those using Brazilian health care services between 1998 and 2008 pointed out an increase in access to health care services in the country, particularly due to the expansion of the FHS program into the poorest geographic regions and with the most vulnerable populations. On the other hand, an increase in hospitalization rates among this population was noticed, which according to these authors could show a gap in access to preventive services or the use of services with higher complexity, such as primary care alternatives ${ }^{(36)}$.

The low scores observed for the access to first contact attribute suggest the persistence mainly of organizational problems that make difficult the use of health care services, taking into account that the PCATool is used to investigate the difficult for scheduling an appointment, working days and hours of the unit, waiting time for service, availability of a phone number for making an appointment or receiving counseling, among other issues.

The longitudinality attribute expresses the presence of a continuous source of care and its use over time, resulting in a relationship between user and professional/health care staff ${ }^{(7)}$. Continuity, translated as longitudinality, is distinguished from other attributes for having two essential characteristics, care over time and focus on the individual ${ }^{(37)}$.

In order to meet the dimensions of this attribute it would be fundamental, besides a regular source of care and lasting therapeutic relationship, the so-called informational continuity ${ }^{(37-38)}$. It concerns using health care records with the purpose of getting to know the user of the service better and facilitating the therapeutic approach ${ }^{(37)}$. In the PCATool, this component was included in the coordination attribute ${ }^{(38)}$.

In this review, some authors used the terms continuity $^{(15)}$ and relationship ${ }^{(14,17,26,28,31)}$ as a translation for longitudinality. It was evident for the author ${ }^{(7)}$ who provided the theoretical basis for the mentioned tool that relationship and continuity are distinct terms, since care continuity represents a succession of appointments with the same professional or visits to the health care unit in a given period of time, geared towards handling problems and not providing care to individuals.

The $\mathrm{PNAB}^{(5)}$ uses the term relationship and defines it as "the creation of closeness and trustworthy relationships between user and health care workers built over time, allowing to deepen the process of jointly responsibility for the health care and, furthermore, increasing therapeutic potential." Consequently, in order to approach PHC in Brazil it would be more adequate to use the term longitudinal relationship, since it is considered the therapeutic relationship between user the health care staff, not centered in the figure of the physician and having the $\mathrm{BHC}$ unit serving as a regular source of health care $^{(38)}$.
It is important to note that in the studies conducted for validating the PCATool-Brazil, children ${ }^{(15)}$ and adult ${ }^{(13)}$ versions, despite the use of the term continuity, the adaptation of the questions scored the relationship health professional/ user criteria. The users are asked, for example, if it is always the same professional who assists them, if they provide enough time for the users to express their concerns or problems, and if the professional knows them more as a person rather than just someone with a health problem.

Therefore, the assumption is that in order for longitudinality to reach all its dimensions, professionals must be sensitive and aware of the population's health needs, and expansion of the access to services and increased actions encouraging the placement of professionals in the communities where they have relationships and continuous training are also needed.

The attribute comprehensiveness presupposes the presence of a variety of services available that meet people's needs, whereas these needs might be related to illnesses or interventions that prevent and promote health ${ }^{(7)}$. By definition, it is up to the primary care service to establish mechanisms for the user to receive diversified health care that meets their needs ${ }^{(14)}$. This attribute considers the service components available and the service provided ${ }^{(10)}$.

Different denominations were also found for this dimension, depending on the tool applied. The PCATool validated for Petrópolis-RJ ${ }^{(14)}$ presents the term service casting, closer to the corresponding term in English comprehensiveness. Two studies ${ }^{(15,19)}$ that used the PCATool-Brazil still separate the component available services (primary and supplementary) and designate the service provided component as promotion orientation.

In this review, the comprehensiveness attribute was generally well-assessed. It must be clearly stated that there is other dimension to the term comprehensiveness that goes beyond the range of available services, in which the health care professional must provide care to the user as a biosocial being who is affected by the environment they live in ${ }^{(39)}$. Consequently, awareness of these aspects would allow the elaboration of health care plans that meet the users' real needs and, indirectly, would contribute to improve the quality of the health care services provided.

The coordination attribute is defined as a continuity measure, whether through the assistance provided by the same professional, or by adding notes in the medical record or both, providing information on follow-up of new and old problems, referring and following-up the user to further levels of care $^{(7)}$. In the PCATool-Brazil ${ }^{(10)}$, the coordination attribute is divided into two components, care integration and information system. Furthermore, it is important to emphasize that it was not possible to make an assessment, in particular, of each component of this attribute, since three studies only showed these results individually ${ }^{(32-34)}$.

The coordination higher scores arise as a result of longitudinality $^{(37)}$. In this review, the mentioned attribute was well-assessed, especially in the FHS. However, the challenges the PHC face in Brazil in order to reach this goal are the limitation of specialized services and available diagnoses and inequality in information systems ${ }^{(40)}$. 
The family orientation attribute takes into account the family as the subject of care, requiring an interaction with the health care team with this social unit and full knowledge of their health problems and tools to approach the family ${ }^{(6-7,10)}$. On the other hand, community orientation presupposes the identification of the community health care needs on the part of the service, through epidemiologic data and direct contact with these individuals, as well as their participation in intersectoral approach programs that allow confronting social determinants ${ }^{(6-7,10)}$.

The expectation was that the FHU would show higher scores in this dimension, since this strategy should foster users' participation and social control. It is suggested that in order to confront this difficulties the health care staff must get the community involved in the action planning process, adopt an acceptance attitude, and clinical and human quality improvement for the professionals involved with PHC, integration with other services, and cultural competence ${ }^{(6)}$ are also needed.

The professional training dimension is presented only in the PCATool version validated for the city of Petrópolis$\mathrm{RJ}$, for being considered by the authors as important for the assessment of PHC. It determines that primary care is a specialized area of knowledge and, as such, it requires specific training and that the health care professionals must be apt to carry out their duties. For renewing PHC and consolidating the network, is it essential to improve the educational aspects of undergraduate and graduate programs, with training focused on PHC. In addition to incentives from permanent educational systems to health professionals, through innovating, active, and student-centered methodologies, rather than those centered in the professor ${ }^{(6)}$.

According to the findings in this review, there is a noticeable correlation between the results and the assumption that the FHU are more oriented towards PHC than traditional BHC units, even with some attributes being rated with low scores. It is believed that $\mathrm{FH}$ services are closer to the PC fundamentals due to the investments made in this model throughout 21 years for the expansion and consolidation of the strategy and policies for institutionalizing the monitoring and assessment of these services.

It is relevant to inform that this systematic review has limitations by using sectional observational studies, including some not yet published in indexed journals. Furthermore, due to the heterogeneity of the results as presented, the meta-analysis was not conducted. The methodological heterogeneity occurred particularly as a result of the observations being carried out with the three versions of the PCATool, with distinct scales and cut-off points for assessing the orientation of the PHC services and, as far as the version used, other attributes/dimensions were also measured.
The authors faced difficulties in finding a tool that allowed reaching a judgment on the quality of the sectional studies. Most of the current quality assessment tools cover all the observational studies (randomized and non-randomized) and, as such, fulfill some criteria that do not apply to cross-sectional designs, which in turn can underestimate the quality of the manuscript.

The amount of articles published on the topic in Brazil is still low, even taking into account the studies that evaluate exclusively the perception of the health care professionals on the PHC attributes, which in turn add to more limitations. In addition, the adaptation and validation of the PCATool in Brazil took place just over a decade ago, which also could corroborate the reduced amount of publications.

Despite these limitations, this is the first review conducted on the topic and its findings could help health care professionals and managers to rethink their practices and search for mechanisms for improving the quality of the services provided. The intention is also to raise interest for new assessment studies on the subject, in a way that it would allow a better approach to the obstacles that hamper a better service orientation towards PC guidelines.

\section{CONCLUSION}

This systematic review demonstrated that users of basic care units assessed as poor the attributes of access to first contact, community and family orientation approach, which are considered essential for a more equitable and competing health care for autonomy and social control, even within FHU. It is important to emphasize that, despite the investments for increasing the supply of health care services, there are still obstacles hampering users' access to basic care services and actions are still being taken without privileging the participation of individuals and the community setting where they live in.

\section{IMPLICATIONS FOR PRACTICE AND RESEARCH}

These results points towards a need for encouraging actions that promote the improvement of the attributes of access, family and community, with emphasis on the basic care units, for example: acceptance with risk classification, increased opening days and hours for users, and improved means of communication (telephone, digital media) between users and the health care services; family involvement for elaborating therapeutic projects for the users assisted; social participation in the primary care teamwork process, by means of promoting opportunities for discussion between these pairs; and support for continuing education to the referred staffs. New studies in the area of service assessment are important for understanding these findings better. 
textos completos. Após leitura integral e aplicação dos critérios de elegibilidade, 14 artigos foram avaliados. Os estudos apontaram que a Atenção Básica tem bom desempenho nos atributos longitudinalidade, integralidade e coordenação e pior desempenho nos atributos acesso de primeiro contato, orientação familiar e a orientação comunitária, mesmo nas unidades básicas com Saúde da Família. Conclusão: Os usuários das unidades básicas de saúde avaliaram como insatisfatórios atributos considerados fundamentais para uma atenção à saúde mais equânime e concorrente para autonomia do usuário e controle social. Infere-se que ainda existem obstáculos que dificultam o acesso dos usuários aos serviços básicos de saúde e que ações do cuidado ainda estejam sendo desenvolvidas sem privilegiar a participação do usuário e o contexto comunitário onde vivem.

\section{DESCRITORES}

Atenção Primaria à Saúde; Avaliação de Serviços de Saúde; Avaliação de Programas e Projetos de Saúde; Revisão.

\section{RESUMEN}

Objetivo: Analizar la evaluación de los atributos de la Atención Básica hecha por usuarios de unidades básicas de salud brasileñas, mediante la utilización de adaptaciones del instrumento PCATool para Brasil. Método: Revisión sistemática de la literatura realizada en las bases de datos Medline/PubMed, LILACS, IBECS, SciELO y BDTD. Resultados: Fueron encontrados 4.405 documentos, seleccionándose 23 textos completos. Tras la lectura completa y la aplicación de los criterios de elegibilidad, 14 artículos fueron evaluados. Los estudios señalaron que la Atención Básica tiene buen desempeño en los atributos longitudinalidad, integralidad y coordinación y peor desempeño en los atributos acceso de primero contacto, orientación familiar y orientación comunitaria, incluso en las unidades básicas con Salud de la Familia. Conclusión: Los usuarios de las unidades básicas de salud evaluaron como insatisfactorios los atributos considerados fundamentales para una atención sanitaria más ecuánime y que concurra a la autonomía del usuario y el control social. Se infiere que todavía existen obstáculos que dificultan el acceso de los usuarios a los servicios básicos de salud y que acciones de cuidado aún se están desarrollando sin privilegiar la participación del usuario y el contexto comunitario en donde viven.

\section{DESCRIPTORES}

Atención Primaria de Salud; Evaluación de Servicios de Salud; Evaluación de Programas y Proyectos de Salud; Revisión

\section{REFERENCES}

1. Organização Mundial de Saúde. Declaração de Alma-Alta. Alma-Alta [Internet]. Genebra: OMS; 1978 [citado 2014 jul. 19 ]. Disponível em: http://www.opas.org.br/coletiva/uploadArq/Alma-Ata.pdf

2. Organização Pan-Americana da Saúde; Organização Mundial da Saúde. Renovação da atenção primária em saúde nas Américas: documento de posicionamento da OPAS/OMS. Washington: OPAS; 2007.

3. Gil CRR. Atenção primária, atenção básica e saúde da família: sinergias e singularidades do contexto brasileiro. Cad Saúde Pública [Internet]. 2006 [citado 2014 jul. 19];22(6):1171-81. Disponível em: http://www.scielo.br/pdf/csp/v22n6/06.pdf

4. Brasil. Ministério da Saúde. Portaria n. 648, de 28 de março de 2006. Aprova a Política Nacional da Atenção Básica, estabelecendo a revisão de diretrizes e normas para a organização da Atenção Básica para o Programa Saúde da Família (PSF) e o Programa Agentes Comunitários de Saúde (PACS) [Internet]. Brasília; 2006 [citado 2014 jul. 19]. Disponível em: http://bvsms.saude.gov.br/bvs/saudelegis/gm/2006/prt0648_28_03_2006_ comp.html

5. Brasil. Ministério da Saúde. Portaria n. 2488, de 21 de outubro de 2011. Aprova a Política Nacional de Atenção Básica, estabelecendo a revisão de diretrizes e normas para a organização da Atenção Básica, para a Estratégia Saúde da Família (ESF) e o Programa de Agentes Comunitários de Saúde (PACS) [Internet]. Brasília; 2006 [citado 2014 jul. 19]. Disponível em: http://bvsms.saude.gov.br/bvs/saudelegis/gm/2011/ prt2488_21_10_2011.html

6. Organização Pan-Americana da Saúde. A Atenção à Saúde coordenada pela APS construindo as redes de atenção no SUS: contribuições para o debate [Internet]. Brasília; 2011 [citado 2014 jul. 22]. Disponível em: http://www1.saude.rs.gov.br/dados/1308159221237APS_Verde_web_final.pdf

7. Starfield B. Atenção primária: equilíbrio entre necessidades de saúde, serviços e tecnologia. Brasília: UNESCO; 2002

8. Sumar N, Fausto M. Atenção Primária à Saúde: a construção de um conceito ampliado. J Manag Prim Health Care [Internet]. 2014 [citado 2015 out. 23];5(2):202-12. Disponível em: http://www.jmphc.com/ojs/index.php/01/article/view/182/139

9. Shi L, Starfield B, Xu J. Validating the Adult Primary Care Assessment Tool. J Fam Pract. 2001;50(2):161-75.

10. Brasil. Ministério da Saúde; Secretaria de Atenção à Saúde, Departamento de Atenção Básica. Manual do instrumento de avaliação da atenção primária à saúde: Primary Care Assessment Tool PCATool - Brasil. Brasília: MS; 2010.

11. Malouin RA, Starfield B, Sepulveda MJ. Evaluating the Tools Used To Assess the Medical Home. Maneg Care [Internet]. 2009 [cited 2015 jul. 15];18(6):44-8. Available from:http://www.managedcaremag.com/sites/default/files/imported/0906/0906.peer_medicalhome.pdf

12. Fracolli LAP, Gomes MFP, Nabão FRZ, Santos MS, Cappellini VK, Almeida ACC. Instrumentos de avaliação da Atenção Primária à Saúde: revisão de literatura e metassíntese. Ciênc Saúde Coletiva [Internet]. 2014 [citado 2015 jul. 15];19(12): 4851-60. Disponível em: http://www.scielo.br/ pdf/csc/v19n12/pt_1413-8123-csc-19-12-04851.pdf

13. Harzheim E, Duncan BB, Stein AT, Cunha CRH, Gonçalves MR, Trindade TG, et al. Quality and effectiveness of different approaches to primary care delivery in Brazil. BMC Health Serv Res [Internet]. 2006 [cited 2014 June 29];6(156):1-7. Available from: http://www.biomedcentral. com/1472-6963/6/156

14. Almeida A, Macinko J. Validação de uma metodologia de avaliação rápida das características organizacionais e do desempenho dos serviços de atenção básica do Sistema Único de Saúde (SUS) em nível local. Brasília: Organização Pan-Americana da Saúde; 2006.

15. Harzheim E, Starfield B, Rajmil L, Álvarez-Dardet C, Stein AT. Consistência interna e confiabilidade da versão em português do Instrumento de Avaliação da Atenção Primária (PCATool-Brasil) para serviços de saúde infantil. Cad Saúde Pública [Internet]. 2006 [citado 2014 mar. 30];22(8):1649-59. Disponível em: http://www.scielo.br/pdf/csp/v22n8/13.pdf

16. Chomatas ERV, Vigo A, Marty I, Hauser L, Harzhein E. Avaliação da presença e extensão dos atributos da atenção primária em Curitiba. Rev Bras Med Fam Comunidade [Internet]. 2013 [citado 2014 jul. 22];8(29):294-303. Disponível em: http://www.rbmfc.org.br/rbmfc/ article/ viewFile/828/587 
17. van Stralen CJ, Belisário SA, van Stralen TBS, Lima AMD, Massote AW, Oliveira CL. Percepção dos usuários e profissionais de saúde sobre atenção básica: comparação entre unidades com e sem saúde da família na Região Centro-Oeste do Brasil. Cad Saúde Pública [Internet]. 2008 [citado 2013 jun. 29]; 24(Sup1):148-58. Disponível em: http://www.scielo.br/pdf/csp/v24s1/19.pdf

18. Oliveira MMC. Presença e extensão dos atributos da atenção primária à saúde entre os serviços de atenção primária em Porto Alegre: uma análise agregada [dissertação]. Porto Alegre: Universidade Federal do Rio Grande do Sul; 2007.

19. Leão CDA, Caldeira AP, Oliveira MMC. Atributos da atenção primária na assistência à saúde da criança: avaliação dos cuidadores. Rev Bras Saúde Mater Infant [Internet]. 2011 [citado 2013 jul. 01];11(3):323-34. Disponível em: http://www.scielo.br/pdf/rbsmi/v11n3/a13v11n3.pdf

20. O'Connor D, Green S, Higgins JPT, editors. Defining the review question and developing criteria for including studies. In: Higgins JPT, Green S, editors. Cochrane Handbook for Systematic Reviews of Interventions. Version 5.1.0 [Internet]. Chichester (UK): The Cochrane Collaboration; 2011 [cited 2014 jul. 18]. Available from: http://handbook.cochrane.org/chapter_5/5_defining_the_review_question_and_developing_criteria_ for.htm

21. Effective Public Health Practice Project. Quality Assessment Tool for Quantitative Studies [Internet]. Hamilton Ontario (CA): McMaster University, Faculty of Health Sciences; c2014 [cited 2014 July 18]. Available from: http://www.ephpp.ca/tools.html

22. Thomas BH, Ciliska D, Dobbins M, Micucci S. A Process for systematically reviewing the literature: providing the research evidence for public health nursing interventions. Worldviews Evid Based Nurs. 2004;1(3):176-84.

23. Armstrong R, Waters E, Doyle J, editors. Reviews in public health and health promotion. In: Higgins JPT, Green S, editors. Cochrane Handbook for Systematic Reviews of Interventions. Version 5.1.0 [Internet]. Chichester (UK): The Cochrane Collaboration; 2011 Mar [cited 2014 July 18]. Available from: http://handbook.cochrane.org/chapter_21/21_4_assessment_of_study_quality_and_risk_of_bias.htm

24. The Joanna Briggs Institute. News of JBI Levels of Evidence [Internet]. Adelaide; 2014 [cited 2015 Oct 27]. Available from: http://joannabriggs. org/assets/docs/approach/JBI-Levels-of-evidence_2014.pdf

25. Moher D, Liberati A, Tetzlaff J, Altman DG. Preferred reporting items for systematic reviews and meta-analyses: the PRISMA statement. PLoS Med [Internet]. 2009 [cited 2015 Oct 26];6(7):e1000097. Available from: http://www.plosmedicine.org/article/fetchObject.action?uri=info:doi/10.1371/ journal.pmed.1000097\&representation=PDF

26. Ibañez N, Rocha JSY, Castro PC, Ribeiro MCSA, Forster AC, Novaes MHD, et al. Avaliação do desempenho da atenção básica no Estado de São Paulo. Ciênc Saúde Coletiva [Internet]. 2006 [citado 2013 jun. 29];11(3):683-703. Disponível em: http://www.scielo.br/pdf/csc/v11n3/30983.pdf

27. Pinto MEB. Promoção à saúde e atenção primária à saúde em Porto Alegre [tese doutorado]. Porto Alegre: Universidade Federal do Rio Grande do Sul; 2012.

28. Elias PE, Ferreira CW, Alves MCG, Cohn A, Kishima V, Escrivão Junior A, et al. Atenção Básica em Saúde: comparação entre PSF e UBS por estrato de exclusão social no município de São Paulo. Ciênc Saúde Coletiva [Internet]. 2006 [citado 2014 abr. 12];11(3):633-41. Disponível em: http://www.scielo.br/pdf/csc/v11n3/30979.pdf

29. Macinko J, Almeida C, Sá PK. A rapid assessment methodology for the evaluation of primary care organization and performance in Brazil. Health Policy Plan [Internet]. 2007 [cited 2014 June 19];22(3):167-77. Available from: http://heapol.oxfordjournals.org/content/22/3/167.full.pdf+html

30. Zils AA, Castro RCL, Oliveira MMC, Harzheim E, Duncan BB. Satisfação dos usuários da rede de Atenção Primária de Porto Alegre. Rev Bras Med Com [Internet]. 2009 [citado 2014 jun. 30];4(16):270-6. Disponível em: rbmfc.org.br/rbmfc/article/download/233/184

31. Pereira MJB, Abrahão-Curvo P, Fortuna CM, Coutinho SS, Queluz MC, Campos LVO, et al. Avaliação das características organizacionais e de desempenho de uma unidade de Atenção Básica à Saúde. Rev Gaúcha Enferm [Internet]. 2011 [citado 2014 abr. 13];32(1):48-55. Disponível em: http://www.scielo.br/pdf/rgenf/v32n1/a06v32n1.pdf

32. Oliveira VBCA. Avaliação da Atenção Primária à Saúde da criança no município de Colombo-Paraná [dissertação]. São Paulo: Universidade de São Paulo, Escola de Enfermagem; 2012.

33. Furtado MCC, Braz JC, Pina JC, Mello DF, Lima RAG. A avaliação da atenção à saúde de crianças com menos de um ano de idade na Atenção Primária. Rev Latino Am. Enfermagem [Internet]. 2013 [citado 2014 jun. 10];21(2):554-61. Disponível em: http://www.scielo.br/pdf/rlae/v21n2/ pt_0104-1169-rlae-21-02-0554.pdf

34. Braz JC. Avaliação da atenção às crianças menores de um ano na Estratégia Saúde da Família em um município da Bahia, sob a ótica dos cuidadores [dissertação]. Ribeirão Preto: Universidade de São Paulo, Escola de Enfermagem de Ribeirão Preto; 2012.

35. Jesus WLA, Assis MMA. Revisão sistemática sobre o conceito de acesso nos serviços de saúde: contribuições do planejamento. Ciênc Saúde Coletiva [Internet]. 2010 [citado 2015 mar. 27];15(1):161-70. Disponível em: http://www.scielo.br/pdf/csc/v15n1/a22v15n1.pdf

36. Macinko J, Lima-Costa MF. Horizontal equity in healthcare utilization in Brazil, 1998-2008. Int J Equity Health [Internet]. 2012 [cited 2015 July 13];11(3):1-8. Available from: http://www.equityhealthj.com/content/pdf/1475-9276-11-33.pdf

37. Haggerty JL, Reid RJ, Freeman GK, Starfield BH, Adair CE, McKendry R. Continuity of care: a multidisciplinary review. BM] [Internet]. 2003 [cited 2015 July 13];327(7425):1219-21. Available from: http://www.ncbi.nlm.nih.gov/pmc/articles/PMC274066/

38. Cunha EM, Giovanella L. Longitudinalidade/continuidade do cuidado: identificando dimensões e variáveis para a avaliação da Atenção Primária no contexto do Sistema Público de Saúde Brasileiro. Ciênc Saúde Coletiva [Internet]. 2011 [citado 2014 jun. 30];16 Supl.1:1029-42. Disponível em: http://www.scielo.br/pdf/csc/v16s1/a36v16s1.pdf

39. Haggerty J, Burge F, Lévesque JF, Gass D, Pineault R, Beaulieu MD, et al. Operational definitions of attributes of primary health care: consensus among Canadian experts. Ann Fam Med [Internet]. 2007 [cited 2015 July 13];5(4):336-44. Available from: http://www.ncbi.nlm.nih.gov/pmc/ articles/PMC1934980/pdf/0050336.pdf

40. Macinko J, Harris MJ. Brazil's Family Health Strategy: Delivering Community-Based Primary Care in a Universal Health System. N Engl J Med [Internet]. 2015 [cited 2015 jul. 14];372(23):2177-81. Available from: http://www.nejm.org/doi/pdf/10.1056/NEJMp1501140

Financial support: Fundação de Amparo à Ciência e Tecnologia do Estado de Pernambuco (FACEPE). Scholarship granted for graduate studies. Process no. IBPG-0364-4.01/12. 